\title{
The Necessity of Hope: A Philosophical and Theological Appraisal
}

\author{
Emeka C. Ekeke, PhD \\ Eyo, Ubong Ekpenyong \\ Department of Religious/Cultural Studies, \\ University of Calabar, Calabar,Cross River State, Nigeria
}

doi: 10.19044/esj.2016.v12n5p371URL:http://dx.doi.org/10.19044/esj.2016.v12n5p371

\begin{abstract}
The world today is full of innumerable uncertainties plaguing humanity. There seem to be a growing concern for the future of the world as various natural phenomena such as earthquake, tsunami, flood, draught, famine and war takes its toll on humankind. Suffering is now on the increase even among the redeemed of the Lord. Many scientists and environmentalists are advocating for the reduction of carbon emission as solution to the perceived climate change. In the midst of these uncertainties hope in the Sovereign, Omnipotent, Omniscient and Immutable God become the only sine-qua-non and the panacea for survival and continued existence. Being a literary research, the paper adopted the qualitative analytical research methodology in its approach and examined the necessity of hope as it pertained to mankind in the midst of suffering. In recommendation, it among others, advocated that a life without hope will eventually fall into despair or retires into status quo of the society. The paper explained that the Christian hope goes beyond the contemplation of philosophy and hinges on the truth as revealed by Christ and the Scripture.
\end{abstract}

Keywords: Hope, suffering, philosophy, biblical

\section{Introduction:}

In this world full of all manner of uncertainties, there is only one thing that can keep one going, hope. The events which are being witnessed today in the world may not be quite new, in that the world has always been plagued with different troubles at different times, but the dynamics of it may be new to the human society. There is decay in all facets of life - ranging from the ecclesiastical to the political, economic and social spheres of life. Human suffering seems to be reaching its apex level as everyday turns out new level of pain and tears not just to humanity but to the entire cosmos. In 
spite of these, the Omnipotent God has promised his abiding presence to God's people in the midst of all these uncertainties. What are the implications of these promises of God to humanity today vis-à-vis our hope in this world of increasing perils and danger? This is the pivot of this paper in which we look at hope from both philosophical and biblical perspectives, the necessity of hope in our present world, the sovereignty of God who is the hope of religious people and the implications thereof for practical life today.

\section{The Concept of Hope}

The mere fact that human beings either do or can hope is a comfort in their present difficult situations. The question is what is hope? In the normal English parlance, Encarta 2009 speaks of hope in its verb form as, “confident desire: a feeling that something desirable is likely to happen...likely hood of success: a chance that something desirable will happen or be possible" (DVD). It further defines it as "wish or desire: something that somebody wants to have or do or wants to happen or be true or a feeling of trust". Since our sphere of discussion is beyond the English literary understanding of hope, we will seek further study of the word and its concept from the philosophical and biblical perspectives.

\section{Philosophical Perspective of Hope}

Brian Treanor (2010) describes hope as the final guarantor of fidelity; "it is that which allows me not to despair, that which gives me the strength to continue to create myself in availability to the other". Treanor (2010) explains further that this kind of reasoning might simply appear to be nothing more than optimism - frequently misplaced, as events too often reveal-that things will turn out for the best. Marcel (1995) in his explanation insists that this is not the case. Following now familiar distinctions, he makes a differentiation between the realm of fear and desire on one hand and the realm of despair and hope on the other.

Hope makes a person look stupid before "wise” people in the face of difficulty. The person who hopes does not accept the current situation as final; however, neither does he or she imagine, expect nor anticipate the circumstance that would deliver him or her from his or her plight, rather he or she merely hopes for deliverance. The more hope transcends any anticipation of the form that deliverance would take, the less it is open to the objection that, in many cases, the hoped-for deliverance does not take place. If a person desires that his or her disease will be cured by a given surgical procedure, it is very possible that this desire might be thwarted. This is what makes hope different from desire. One's desire may be thwarted but one's hope does not give way even in the midst of unforeseen, unbearable and hopeless situation. This is why the Scripture says about Abraham "Against 
all hope, Abraham in hope believed and so became the father of many nations..." (Romans 4:18)

Mitchell Abidor (2009) sees hope and desire from a divergent viewpoint. He explains that when we hope for something grand, we draw from the beauty of the goal the courage to brave all obstacles. If the chance of reaching it fades away, the desire grows accordingly at the same pace. The farther from reality lies the goal, the more desirable it is, and since desire is the supreme force it has the greatest amount of force at its service (p.1). To this great scholar hope simply uses desire as a great weapon to achieve its goal. This argument looks reasonable when seen from the fact that no person could stand the struggle of life without hope in something that looks real or perceived to be real.

Hope does not walk alone nor does it resign itself to fate rather it is active yet patiently waiting for what it is hoping for. Marcel puts it this way: "Hope consists in asserting that there is at the heart of being, beyond all data, beyond all inventories and all calculations, a mysterious principle which is in connivance with me” (Marcel 1995, p. 28). Brian Treanor (2010) describes such hope as being characterized as an "active patience". He explains further that "the assertion contained in hope reveals a kinship with willing rather than desiring ‘inert hope’ would be an oxymoron” (p. 15).

Schumacher (2003) explains that "hope is an intentional movement toward a pre-existent object.” This means according to Leitane (2005:2) that the object of hope is existent in the not-yet-being. Therefore the object of hope is not yet possible to reach. Process of hoping is providing vitality for this intentional object towards which hope is a movement. According to Leitane (2005) "Not-yet-being is being, which is not yet reachable as being. It can be being in future reality" (p.2). This means that at the same time human being is capable to conceive not-yet-being as such. For human being not-yet-being is a part of reality, which affects all actions and provides existence of human being. Hope as intentional movement presupposes the hoping human being. This human being can be characterized as vital process making - hoping subject. Hoping subject can have hope or hopes as such or just participate in hoping process in which he or she is involved. Human being is capable for vital processes such as hoping. Bloch (1986: 21) explains in his The Principle of Hope that hope is only human, not for animals. Thus for human being act of hoping is of great advantage. We must move on to more and more hope.

Inga Leitane (2005: 3-4) enumerated what he termed the main characteristics of hope which we have adopted in this paper to include: (1) hope is accompanied by minimum of certitude and assurance with respect to the possible possession of the thing hoped for, the thing for which the human being aims. To Leitane, this minimum must be in existence if not such 
presumed hope is nothing but desire. (2) "The object hoped for is good, understood very broadly - in the ontological sense. The thing must be good in a certain respect, something desirable for the human being. In order to be able to speak of hope, there must be an inclination toward the object; there must be a desire on the part of human being for the object, a hunger or thirst for the object, which falls under the aspect of goodness". This characteristic shows that hope's object must be good in the general sense. What an individual hopes for must be goodness to be seen as hope indeed. (3) Leitane further explains that the object hoped for must be difficult to obtain. We do not hope for something that demands no effort on the part of the human being. Hope should not be on something that looks cheap which could be purchased at a common price and place. (4) An object of hope is not something that is necessarily realized. This is where hope may look very difficult because what an individual hoped for may not actually be realizable in this present age. (5) Another important characteristic of hope is the fact that the object of hope lies beyond the control of the one who hopes. In this case, the one who hopes may or may not receive what he/she hopes for; and finally (6) Hope is always ordered to something that represents a good for the hoping subject. This aspect of hope consists in the attitude of expectant waiting. Expectant waiting can be directed either to good or an evil. But hope is hope only if it is directed to something good. If expectant waiting is directed to evil, then we are speaking of fear.

From the above philosophical explanations, it is very easy to deduce that hope has its stronghold on that which is not seen but which it strongly believes will eventually be made manifest. He or she therefore waits patiently for it. Even when what is hoped for does not come at the time expected, the hopeful remains in hope even unto death trusting that if it does not come in this present world, it will surely come in the world to come. This is one great principle that strengthens Judo-Christian faith.

\section{Biblical Perspective of Hope}

The Old Testament Perspective: Etymologically, it needs to be pointed out that in the Old Testament there is no distinct Hebrew word that can be translated as the English word 'hope' . Hence, Easton points out that, "in the Old Testament there is no Hebrew word that has the exact force of 'expectation of some good thing,' so that in the King James Version 'hope' (noun and vb.) stands for some 15 Hebrew words, nearly all of which in other places are given other translation" (Easton 2006). On the other hand, some other translations have attempted to be more systematic and have mostly often translated the wordsmachseh (Jer 17:17; Ps 40:4; 65:5, etc.),tiqrâh (Ezek 37:11), as hope and have variously been used in 
different senses thus in the Old Testament.

The lack of specificity as it applies to any particular word being etymologically translated as hope in the Hebrew language does not have any undervaluation of the concept of hope within the Hebraic religion. In the Old Testament as well as in other spheres, hope has to do with expectation. There is no neutrality in expectation, an expectation is either good or bad, which therefore evokes either hope or fear. In the Old Testament concept, "hope as expectation of good is closely linked with trust, and expectation is also yearning, in which the element of patient waiting or fleeing for refuge is emphasised” (R. Bultman 1991). As long as there is life, there is hope (Eccl 9:4). Hope in Judaism does not mean a consoling dream of imagination which causes one to forget the present troubles or warn of its uncertainty as it is in the Greek philosophy, but the life of the righteous is grounded on hope, and it is a sign that all things are well. Hope is essentially directed towards God whom human beings hope will deliver them from their woes. Hopeful trust is always a demand from God' s people even in their moments of danger (Jer 17:17; Joel 3:16; Ps 31:24; 33:18, 22; 39:7; 46, etc.). This is the general confidence that God will protect and help God' s people who are expected to exercise faith. Butlman further points out that

If God's expected help delivers from present distress, it is more specifically thought of as the eschatological help which puts an end to all distress. The attitude of expectant and confident hope increasingly expresses the realisation that everything in the earthly present is provisional, and it thus becomes increasingly hope in the eschatological future (R. Bultman 1991).

In the Rabbinic Judaism, the concept of hope is built around the messianic expectation which is bipolar in nature - the expectation of the deliverance of God' s people and the vengeance or judgment of their oppressors. These positive and negative expectations lead Rengstorf to rightly point out that,

The positive relates to the fulfilment of Jewish hopes, the negative to the expectation of the judgment which at the commencement of the Messianic age will smite the ungodly who as the enemies of God are always the enemies of His people and who in conflict against the Jews will draw down on themselves the wrath and vengeance of God (Rengstorf 1991).

Though this messianic hope finds its fulfilment in God, God has 
made it to be dependent on the relationship of religious people to God and to will. Hence in bringing this hope to pass, God is not working alone, human beings must play a part as they are expected to usher in the messianic kingdom through the keeping of the Law and strict observance of religious rites. It is only God who can decide when this day of hope will come, and the assessment is wrapped in impenetrable darkness. The messianic hope comes with the establishment of God' s kingdom of righteousness which will favour God' s people.

In Hellenistic Judaism also hope belongs to life (Ecclus 14:2) and it is extinguished only by death (Ps. Sol. 17:2). The sick man hopes for healing (2 Macc 9:22); the hope of the wicked is in vain (Wis 3:11) and when they die there is no hope for them. Contrary to this, the righteous have hope even in their death because their hope is fixed on God, hence there is no need for them to fear (Ecclus 31:16; 1 Macc 2:61). According to Bultman, "their hope is in the mighty God who is their protection and help in general and also in particular need" (R. Bultman 1991). Generally, in the Old Testament religious thought, the varieties of this hope are countless, but the form most perfected and with fundamental significance for the New Testament is the firm trust that at a time appointed God, in person or through His representative will establish a kingdom of righteousness.

The New Testament Perspective: In the New Testament there are two main perspectives of hope. Travis rightly points out it can either be defined either as "the object of hope, namely Christ and all that his final coming implies, or the attitude of hoping" (Travis 1991). In this work, our concern will be on the later, though without losing sight of the former, for both of them in the Christian faith cannot be divorced from each other.

Conceptually, According to Russell, the New Testament "hope has deep roots in the OT, where KJV 'hope' translates a variety of Hebrew words, which mean 'confidence' , 'trust' ,' 'safety' , etc., sometimes so rendered in more modern versions" (Russel 1987). Etymologically, the word hope is from the Greek word elpizō(verb) and elpis (noun) which is often translated as 'hope', 'trust' (sometimes as 'faith' in KJV), denotes the sense of anticipation usually with pleasure; expectation (abstractly or concretely ) or confidence." (Strong 1991). Hence the usage of elpizein in Luke 6:34; 1 Cor 9:10; 2 Cor 8:5; 1 Tim 3:14; Acts $16: 19$, etc. speaks of expectation, however, where such expectation relates to persons, we have the trust which is typical of the Old Testament concept of hope (cf 2Cor 1:13; 5:11; 13:6, etc.). Sometimes, the idea of hope is used interchangeably with the word pepoithēsis which is often translated as 'confidence' or 'trust' as in 2Cor 1:15; 8:22; 10:2. Bultman rightly 
opines that, "in 1 Cor 13:7 hope, like love, is obviously directed to men, though for Paul this attitude rests on the corresponding relationship to God, as shown by the natural transition from the one to the other in v. 13" (R. Bultman 1991).

Generally, in the New Testament, where hope is fixed on God, it embraces at once the three elements of expectation of the future, trust, and the patience of waiting. Hope cannot count or depend on controllable factors or depend onblepomenōn (Heb. 11:1 Nestle-Aland Greek-English New Testament), but trust in the divine future. Reason for this is that the visible world and all that which is in it are not just temporal but belong to the sphere ofsarz in which no hope is to be found. This Pauline thought is a carried over thought from the Greek world-view where earthly things are mundane while the spiritual are eternal and good. Hence, there is no hope in this world. This accounts for Paul saying, "if for this life only we have hoped in Christ, we are of all people most to be pitied" (1 Cor 15:19 NRSV). Hope constitutes part of the Christian experience in this world and does not concern itself with the realisation of human earthly dreams about the future, but in the confidence of God's gift that awaits the consummation of time.

In the Johannine literature, the wordelpisis almost lacking except in Jn 5:45 and $1 \mathrm{Jn} \mathrm{3:3,} \mathrm{andpistis} \mathrm{(confidence,} \mathrm{trust,} \mathrm{etc.)} \mathrm{is} \mathrm{rather} \mathrm{used,} \mathrm{but} \mathrm{the}$ concept of hope is vividly presented in the eschatological teachings of this corpus. Especially in those texts of the New Testament which have strong bias to the Old Testament, the emphasis on eschatological future is prominent, except in some texts like Col 1:5; 1 Tim 4:10; Titus 2:13; 3:7, cf. 1 Peter 1:3. 13 where there is reference to resurrection and/or the resurrection of Jesus Christ. In the real sense, the New Testament sees the Old Testament hope and eschatology finding its fulfilment already in the mission of Jesus Christ. For believers therefore, Christ is seen as their hope. Trust in God' $s$ act remains the major hope of the New Testament Christendom.

It is good to point out that there is no explicit reference toelpis in Jesus' teachings, but he taught "his disciples not to be anxious about the future, because that future is in the hands of a loving Father" (Tasker 1993). Apart from this teaching, Jesus also taught his disciples that after his resurrection, his presence will be with them always coupled with theparaklettos (the Holy Spirit) which will be given to the believers to be with them in the midst of life' s surging sea. This is meant to inspire hope in believers because of God' s abiding presence in their lives. Hence, Jesus said to his disciples "I am with you always to the end of the age" (Matt 28:20 NRSV). This existence of hope makes it impossible for the believers to be satisfied with 
the transient joys of this world and also acts as the stimulus to purity of life (1Jn 3:2-3) apart from enabling a believer to suffer cheerfully in the midst of life' s storm.

On the general parlance, hope means to look forward expectantly for God' s future activity, and the ground of hope, is God' s past activities in the creation, history of God' s people and majorly, God's redemptive work in Jesus Christ. Hope is not merely a private matter for individual believer since God' s kingdom is universal, "hence the broader, socio-political dimension of hope has become prominent in modern theology" (Travis 1991). Hope also is not a utopian concept, it is progressive but not perfected in this world, for perfection will only come by God' $s$ act at the final coming of Jesus Christ. Hence, "human beings can cope with human failure without despair because they trust the God of hope (Rom 15:13) whose kingdom is surely coming" (Travis 1991).

Summarily, hope from the biblical perspective either from the Old Testament or the New Testament has its anchor on the omnipotent, omnipresent, self-existent and immutable God whose work in the creation, deliverance of the covenant people (Israel of the Old Testament) and the work and life of Jesus Christ have become the believer' s consolation that God will not change in giving hope to the New Testament covenant people.

\section{The Necessity of Hope in the World Today}

Man is inundated on all sides today with all forms of scientific and philosophical discovery and reasoning. Science in using the empirical method in the discovery of certain things that were hitherto supposedly hidden has claimed omnipotent. It shows by its arguments that anything that cannot be empirically proven is false and therefore should be discarded. To such bigots who have no place for hope in their lives, scientific advancement has simply become their god. Yet, a careful look at the various scientific processes ever developed, it is very glaring that no scientist ever entered into laboratory without having a degree of hope that what he or she is about to do will be successful either on the short or long run. Ekeke (2006) corroborates this view when he said that hope is "indispensable for everyone believes and hopes for something. No one can endure the stress and cares of life without hope in something. Pantheists cannot prove that everything is God. Pragmatists cannot prove that what will count for them in the future is what works for them now. The agnostics, on the other hand, cannot prove that it is impossible to know one way or the other" (p. 69). He argues further that hope and faith are indispensable to modem man, even if he chooses to believe only in himself.

Furthermore, the world today has become more religious than 
Auguste Comte predicted in his three stages of human development. Auguste Comte, the founder of classical positivism and inventor of the term sociology, posited that the human mind passes through three successive and different theoretical stages of development. These stages are: first, the theological or fictitious stage; second the metaphysical or the abstract stage and thirdly, the scientific or positive stage (Ekeke, 2011: 198). Comte in his argument in favour of positivism explains that the theological stage "is the starting point where the human mind seeks the essential nature of beings, the first and final causes and absolute knowledge was attributed to the supernatural beings” (qtd in Okon, 2005: p.26, Ekeke, 2011: p.198). This could be seen as the religious stage.

According to Comte, the second stage is where the human mind speculates on abstract forces that are inherent in all beings" (qtd in Okon, 2005: 26, Ekeke, 2011: 198). The third and final stage according to Comte has "nothing to do with the vain search after supernatural or absolute notions or origin of the universe but is focused on the study of natural laws through reasoning and observations” (Ekeke, 2011: 198). This final stage is the scientific one. These stages have been described by Bourdeau as not just a philosophy of science as was believed in the $19^{\text {th }}$ century but a political philosophy(2011: p.2). He believed that Comte was interested in the reorganization of the society.

From Comte's point of view, whether a philosophy of Science or a political philosophy, it is very glaring that he expected a time when religion and religious views will completely be abolished in human reasoning and society. He longed for a time when man will no longer have anything to do with religion or religious issues. This, from our perspective, will include such religious terms like hope, faith, trust in God in the midst of suffering and others.

A careful look at the present world reveals that Comte was totally wrong. This is because there is a great resurgence of religion in human affairs. Religion has become so strong that issues of governance and politics are now being determined based on religious affiliation or ideology.

Again, the catastrophic nature of natural and destructive occurrences today have defied the wisdom and philosophy of the learned to the point that it is only hope in that which is immutable, sovereign, eternal, omnipotent, omnipresence and omniscience could sustain an individual thereby enabling him or her to continue to forge ahead despite all odds. Science has proven in many instances to be wrong in predicting future events. Even where they are right in their predictions do not have any reasonable solution to such events like tsunami, earthquake, flood and other UFOs in the space. This means that man with the armament of scientific discoveries at his disposal cannot guarantee world peace without hope in a supernatural being. On the other 
hand, the various philosophies of the world have not been able to produce peace or a brighter future for man. It is these facts that make hope a-sinequa-non in human existence.

It is here that the Christian faith has so much to offer. It is a religion full of hope. Hope that transcends the grave. Hope goes beyond philosophy and science. Hope keeps the suffering not to despair because he or she knows that the Redeemer is alive. This hopeful does not commit suicide because of hardship, hunger and starvation but believes there is a way out of the present situation which will be revealed very soon. Religion especially Christianity has a message of hope which is embedded in the sovereignty of God and his supernatural intervention in human affair.

\section{The God of Providence}

The knowledge of God is very pivotal to our understanding of God's great promise of hope in the midst of human suffering, hence at this point in this paper, our attention is turned towards the sovereignty of the God who has promised to be with His people always. The Shorter Catechism points out that "God's works of providence are His most holy, wise, and powerful preserving and governing all his creatures and all their actions” (Boettner 1932), and this is clearly expressed in the scriptures that all things outside of God owe not merely their original creation, but their continued existence, with all their properties and powers, to the will of God. God upholds all things by the word of God's power (Heb 1:3), and it is in God that we live, and move and have our being (Acts 17:28). We need to further explore the being of this God and place it in perspective so that we can understand the promise of God as it pertains humankind in the midst of suffering.

First of all we need to point out that this God of providence is a selfexistent God whose life is not dependent on any being. God is uncaused and exist by the necessity of His own Being. Berkhof points out that the idea of God's self-existence was generally expressed by the term “aseitas, meaning self-originated, but the Reformed theologians substituted the term with independentia (independence), as expressing, not merely that God is independent of His Being, but also that He is independent of everything else" (Berkhof 1991). This is why in the Burning Bush God revealed God's name to Moses as hwhy (Ex 3:14), an expression that have to do with selfexistence. It is only as the self-existent and independent Being that god can give assurance that God will remain eternally true to the promise He has made to His people (see Jn 5:26; Ps 94:8ff; Isa 40:18ff, etc.).

The second point of consideration about this God whose promise breeds hope in the midst of human suffering is that, God is immutable - i.e. God is perfect and devoid of change in his being, life, purpose and promises. Though anthropomorphically, scripture speaks of God as repenting of what 
God wanted to do, or changing His mind in respect of sinners, etc, these are only human expressions, but the immutability of "God does not immobility, as if there is no movement in God” (Berkhof 1991). Scriptural texts such as Ex 3:14; Ps 02:26-28; Isa 41:4, etc. teach of this immutability of God. Hence Walter Smith says, "We blossom and flourish as leaves on the tree, and wither and perish - but nought changeth Thee" (The Church of Scotland 1927). God cannot change for the better or worse. This is why Packer points out that "what God planned from eternity, and all that He planned from eternity He carries out in time, and all that He has inn His word committed Himself to do will infallibly be done” (Packer 1973). God's promises of an abiding presence in the midst of suffering cannot also change.

Our next level of understanding of this God of providence is to see God through the pages of scriptures that speak of the Lordship of God. In this attribute, God is presented as a sovereign who is all-powerful, and this is vividly expressed in the question, "is there anything too hard for the Lord?" (Gen 18:14). This same omnipotent nature of God is "repeated in God's promise to restore and liberate Jerusalem in the face of its imminent destruction by Babylon army (Jer 32:27)” (Milne 1993). The omnipotent nature of God is also found in the New Testament in passages like Lk 1:37; Mk 10:27; Acts 17:27-28, etc. The implication of this is that no situation no matter how ugly is beyond the power of God to deliver God's people.

The fourth understanding of the God who has promised an abiding presence to humanity in the midst of suffering is that this God is omnipresence. By this, it means that God is present everywhere - God is present and sees the wickedness that is ravaging the earth, the good deeds of the saints (that will not go unrewarded), the things done in the dark as well as in the light. When it seems as if wickedness is triumphing and injustice are unchallenged, God knows and sees all (Ps 66:12; Isa 43:2; Acts 23:11). When the three Hebrew boys are thrown into the fiery furnace, God was present even in the fire. The omnipresence nature of God is related not only in space but also in time where God is said to be eternal. There is therefore no moment before him or after him. That is why Jesus promised to be with his disciples till the end of the age. God is in charge of events of today as well as the events of tomorrow.

Before looking at the implications of our hope on this omnipotent God who has promised His ever abiding presence with His people in the midst of suffering, we need to reiterate that that this God is omniscience that is, God is all-knowing (Ps 139:1-12). Milne points out that, "the practical implications are therefore similar, disturbing and yet reassuring [for] God sees and hence knows all” (Milne 1993). With God there are mysteries but not mistakes. God's knowledge is perfect, so God knows more than what mortals know. God knows where the pains of today are leading 
humanity toward under His providential care.

Through the nature of God ranging from God's self-existence, immutability, the Lordship of God manifested in God's sovereignty in his omnipotent, omnipresence (both in time and space) and omniscience, the scripture teaches about the providential act of God who is always interested in the welfare of His people. Hence, even in the midst of life's uncertainty, God calls His people to put their trust and hope in the One who has never failed. The question is what is the implication of this knowledge of God to the twenty-first humanity in the face of suffering?

\section{Implications of Hope in God}

Hope in God is a great energizing instrument of the Christian faith. When hope disappears, the Christian's only choice will be to reconcile himself or herself either to the status quo and live in grim submission to it, or plunge into despair and is overcome by it. Christians' hope in God has double dimension. The first dimension focuses on the present world where all manner of sufferings abound. In this aspect of hope, the Christian sees the Sovereign God as being capable of supplying his every need. The Christian in this instance prays with the assurance that God will surely provide his needs. Paul knowing the importance of this kind of hope exhorted the Philippians "My God shall supply all your needs according to his riches in glory by Christ Jesus” (Phil. 4:19).

This assurance is what drives the Christian to declare the righteousness of God wherever he goes with the hope that the efficacious blood of Jesus will wash those who believe. It is this hope that motivated the missionaries to sacrifice their lives for the Gospel to at least save some. This kind of hope enables Christians to abandon the dominion and mandate to despair of any triumph of the gospel or of righteousness in the world. It stirs the inner-man with assurance and vigor in preaching the gospel with the hope of a cultural transformation where the salvation of Christ reaches "far as the curse is found," thereby making Christians not to become deserters from the army of Christ that has been commissioned to follow Him in the subduing of all His foes (Psalm. 110: 1-3). It is this kind of hope that makes Christians heavenly conscious and earthly useful. He is energized to labor not only for the salvation of souls but also for the transformation of all nations and all of life.

The second dimension of this hope is the eschatological. Paul challenges the Christians when he said "If only for this life [in this world] we have hope in Christ, we are to be pitied more than all men” (1 Cor. 15: 19 NIV). This is the hope of eternal life. It is this hope that makes Christians different. Yes, this is the hope for the resurrection and the final victory at the end of history when Christ comes in power and great glory. William O. 
Einwechter explains that "since their hope is exclusively in a heavenly rest, they devote all their energies to prepare their own souls and the souls of others for eternity” (2008: 3). This was the kind of hope the early Christians had that made them choose the path of martyrdom when it became inevitable. A Christian with this kind of hope sees every circumstance surrounding him/her as working out something good for him. He/she concludes with Paul when he addressed the Romans "And we know that in all things God works for the good of those who love him, who have been called according to his purpose” (Rom. 8: 28 NIV).

\section{Conclusion}

Hope is very necessary in this relative and conventional world we live in. Without hope, we become slaves to pessimism that leads to negative and self destructive states of mind. Hope should not be seen as a big dilemma. The real problem is that too many people in the world do not have any. Whether it is a case of suffering in a third world country or in Beverly Hills, lives devoid of hope in this modern age are far too prevalent.

Hope contributes to a positive outlook on life. It is until you have some sense of optimism for the future, life can be very bleak. It is through pessimism and negative thinking that we create a lot of our suffering. Hope is a necessary ingredient for a satisfied, peaceful life, and it is very sad to see that there are some who want to twist it around into something to avoid either because of their religious orientation or because of their philosophical reasoning

Hope makes us see the possibility of effecting a positive change in the world. We need to believe that the world can be improved beyond compromise that it is at least possible that no one has to suffer, even if we recognize that the probability of ever realizing that vision is miniscule. That hope drives us, makes us seek new solutions, take risks, work harder, solve problems. Without it we are simply naïve. We can see hopelessness as knowing about suffering but doing nothing to address it. So we accept our brutal imperfection, and go on hoping and working to make a difference instead of falling into despair. To the Christians who trust in the Almighty God, hope is necessary for the present age and for the world to come.

\section{References:}

Abidor, Mitchell. (2009). The Philosophy of Hope. Retrieved from http://marxists.org/ on 7/17/2012

Berkhof, L. (1991). Systematic Theology. Grand Rapids: Wm. B. Eerdmans Publishing Co.

Bloch, Ernst. (1986). The Principle of Hope. Cambridge: MIT Press Boettner, Loraine. (1932) The Reformed Doctrine of Predestination. 
Phillipsburg: Presbyterian and Reformed Publishing Company Bourdeau, Michel. (2011). “Auguste Comte” in Eward N. Zalta (ed). The Stanford Encyclopedia of Philosophy. Summer Edition, (Retrieved from http://www.plato.standford.edu/archives/sum2011/entries/comte/ on 6/20/2012

Bultman, R. (1991a) "The Hope of Hellenistic Judaism." In Theological Dictionary of the New Testament, edited by Gerhard Kittel, \& Gerhard Friedrich, translated by Geoffrey Bromiley, DVD. Grand Rapids: WM. B. Eerdmans Publishing Company

Bultman, R. (1991b). "The OT View of Hope." In Theological Dictionary of The New Testament, edited by Gerhard Kittel, \& Gerhard Friedrich, translated by Geoffrey W. Bromiley, DVD. Grand Rapids: WM. B. Eerdmans Publishing Company

Bultman, Rudolf. (1991c). "The Early Christian Concept of Hope." In Theological Dictionary of the New Testament, edited by Gerharad Kittel, \& Gerhard Friedrich, translated by Geoffrey W. Bromiley, DVD. Grand Rapids: WM. B. Eerdmans Publishing Company

Easton, Burton Scott. (2006). "Hope." In International Standard Bible Encyclopaedia, edited by James Orr, DVD. Chicago: The Howard-Severance Company

Einwechter, (2008). The Puritan Board "Practical Implications of the Postmillennial Hope"

Ekeke, Emeka C. (2006). "The Limitations of Science and Refutation of Scientism” African Journal of Religion, Culture and Society. 1(1): 53-59

Ekeke, Emeka C. (2011). "Religion and the Limitation of Science” in Etim E. Okon (ed). Readings in the Scientific Study of Religion. Calabar: U of Calabar P: 198-209

Leitane, Inga. (2006). "Hope Pro/Cotra Fear” in $2^{\text {nd }}$ Global Conference,Freeland Oxshire 2006 Retrieved from http://www.interdisciplinary.net on 7/18/2012

Marcel, Gabriel. (1995). The Philosophy of Existentialism. Trans. Manya Harari. New York: Carol Pub Group,

Milne, Bruce. (1993). Know The Truth - A Handbook of Christian Belief. Leicester: IVP,

Okon, Etim E. (2005) “Contemporary Religious Thought”. University of Calabar, (Unpublished mimeograph)

Packer, J. I.(1973). Knowing God. Illinois: IVP,

Rengstorf. (1991). "Hope in Rabbinic Judaism." In Theological Dictionary of the New Testament, edited by Gerhard Kittel, \& Gerhard Friedrich, translated by Geoffrey W. Bromiley, DVD. Grand Rapids: WM. B. Eerdmans Publishing Company,

Russel, Emmet.(1987) "Hope." In New International Bible Dictionary, edited 
by J. D. Douglas, 448. Grand Rapids: Zondervan Publishing House,

Schumacher, Bernard. (2003) Philosophy of Hope: Josef Pieper and the Contemporary Debate on Hope. New York: Fordham University Press, Strong, James. (1991). A concise Disctionary of the Words in the Greek Testament. Massachusettes: Hendrickson Publishers, Tasker, R. V. G. (1993). "Hope." In New Bible Dictionary, edited by J. D. Douglas, 489-490. Leicester: IVP,

The Church of Scotland. (1927). The Revised Church Hymnary. Glasgow: OUP,

Travis, S H. (1991) "Hope." In New Dictionary of Theology, edited by Sinclair B Ferguson, \& David F Wright, 321-322. Leicester: IVP, Treanor, Brian (2010) “Gabriel (-Honore) Marcel” in Stanford Encyclopedia of Philosophy edited by Edward N. Zalta, Retrieved from http://plato.stanford.edu/entries/marcel/ on 7/19/2012 